\title{
THE APPEAL TO EASINESS IN ARISTOTLE'S PROTREPTICUS
}

\author{
Matthew D. Walker
}

[Uncorrected draft. To be published in Ancient Philosophy 39 (2019). Please cite only the final published version.]

Aristotle's Protrepticus sought to exhort its audience to engage in philosophy ( 40.2-3/B53; cf. 6, 37.7-9/B8). ${ }^{1}$ The Protrepticus is now lost. But work by D.S. Hutchinson and Monte Ransome Johnson (2005) has confirmed earlier speculation - initiated by Ingram Bywater (1869) - that Iamblichus preserves large passages of the work in his own Protrepticus. Hutchinson and Johnson 2018 argue that significant portions of the Protrepticus also appear in Iamblichus' De Communi Mathematica Scientia (DCMS), and that the Protrepticus was originally a dialogue.

In passages preserved in Chapter 6 of Iamblichus' Protrepticus (at 40.15-41.2/B5556), Aristotle offers three linked arguments for the claim that philosophy is easy. (I number the arguments in the translation that follows.)

[1] For, with no pay coming from people to those who philosophize, on account of which [the latter] would have labored strenuously in this way, and with a great lead extended to the other arts, nevertheless their passing [the other arts] in exactness despite running a short time seems to me to be a sign of the easiness about philosophy. [2] And further, everybody's feeling at home in it and wishing to occupy leisure with it, leaving aside all else, is no small sign that the close attention comes with pleasure; for no one is willing to labor for a long time. [3] And the use [of wisdom] differs most from all others [i.e., all other arts and sciences]; for [philosophers] are in need neither of tools nor of places for their productive work;

\footnotetext{
${ }^{1}$ I use Pistelli's 1888 edition of Iamblichus' Protrepticus. I cite passages primarily by reference to the Pistelli chapter, page, and line number, and then by the "B" numbering used in Düring's 1961 reconstruction. For the DCMS, I use Festa's 1891 edition. I have consulted various translations (Düring's, as well as Hutchinson and Johnson's excellent reconstruction-in-progress), but translations unless otherwise noted are my own.
} 
rather, wherever in the inhabited world anyone sets down thought, it touches on the truth as if it were equally present everywhere. ${ }^{2}$

These linked arguments - which I call (1) the progress argument, (2) the pleasure argument, and (3) the resource argument - also appear in verbatim parallel passages of Chapter 26 of Iamblichus' DCMS (82.17-83.2). These Aristotelian arguments are as striking as they have been underexplored.

In appealing to, and defending, philosophy's easiness in a protreptic work, however, Aristotle faces an obvious worry - a normative worry that arises independently of the precise content of these arguments. In turning its audience toward an end or pursuit, a protreptic aims to establish that end or pursuit's choiceworthiness. In the Protrepticus, Aristotle aims, more specifically, to establish that philosophy is choiceworthy for its own sake (7, 43.12-25/B68-69; 9, 51.8-15/B18-19; 9, 51.16-52.5/B17; 9, 52.16-20/B42; 9, 53.15-26/B44; cf. DCMS 23, 70.26-71.4). But easiness, the worry goes, has only a tenuous link with the sort of choiceworthiness that Aristotle attributes to philosophy. This obvious normative worry has three parts:

(1) The Sufficiency of Easiness?: According to Aristotle, sleeping with another's wife, wounding others, and bribing officials are all easy ( $E N \vee 9.1137 \mathrm{a} 6-9)$. Yet these, and many other, easy activities lack choiceworthiness for their own sakes. So, easiness is not sufficient for such choiceworthiness.

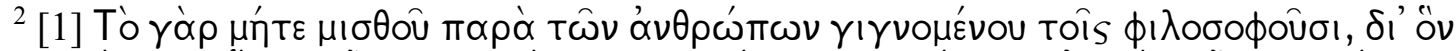

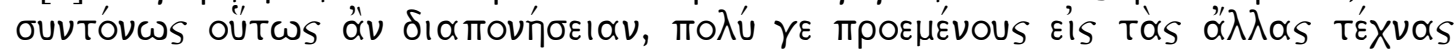

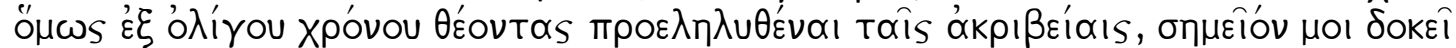

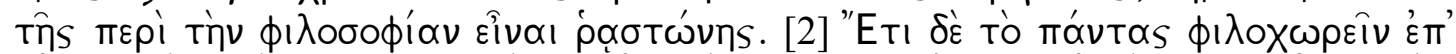

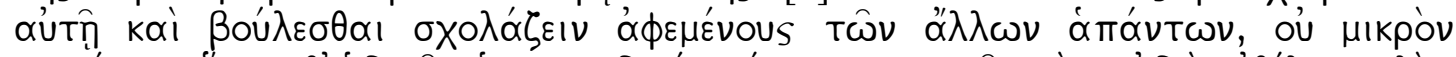

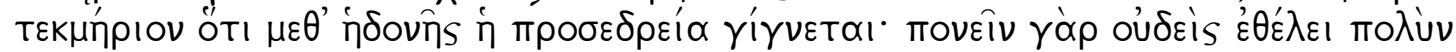

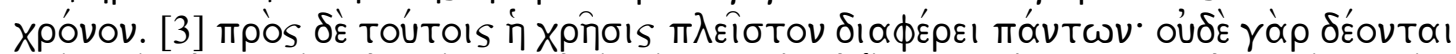

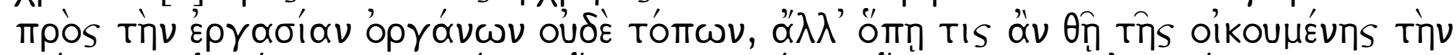

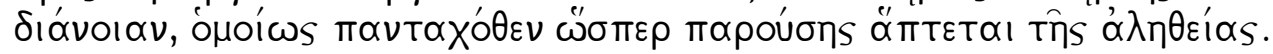


(2) The Necessity of Easiness?: Aristotle identifies certain difficult activities as good and choiceworthy for their own sakes. Consider, for instance, his remarks on ethically virtuous action. Hitting the intermediate - in the right way, at the right time - is "not for everyone, nor easy; hence, the 'well' is rare and praiseworthy and fine" (EN ii 9.1109a2830; cf. ii 6.1106b31-33; ii 9.1109b14-16; iv 11.1126a32-b9; viii 4.1156b25; ix 10.1171a1920; Magna Moralia i 9.1186b32-a4). Similarly, being just is not easy ( $E N$ v 9.1137a5-6). So, difficulty seemingly does not preclude - and easiness is apparently not required for choiceworthiness as an end. ${ }^{3}$

(3) The Superiority of the Difficult?: Aristotle occasionally identifies what is more difficult as greater ( $\mu \varepsilon \hat{\zeta \zeta}$ ) $)$, or more valuable, than what is easier. "And in general the more

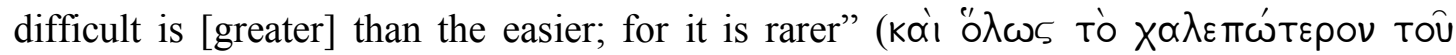

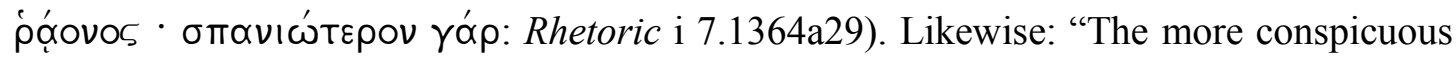
[is more valuable] than the less [conspicuous], and the more difficult [is more valuable than the less difficult]. For we appreciate more having that which is not easily acquired" (To

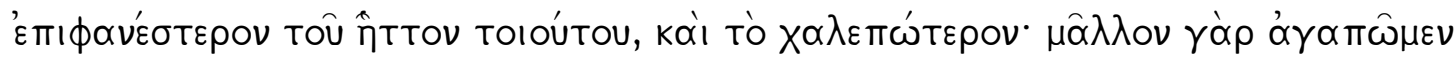

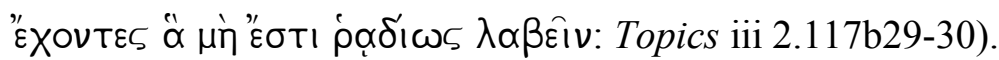

In sum, easiness is neither sufficient nor necessary for choiceworthiness as an end; moreover, what is difficult appears to be more valuable than what is easy. Therefore - this obvious normative worry goes - if the Protrepticus seeks to exhort its audience to pursue philosophy on the basis of philosophy's easiness, then the Protrepticus provides the wrong sort of hortatory appeal. Philosophy's easiness is one matter, philosophy's choiceworthiness as an end, another. Those whom Aristotle must persuade to philosophize on the basis of philosophy's easiness, the thought goes, might seem dubious candidates for philosophers. Hence, the Protrepticus' easiness arguments confront us with the puzzle of

\footnotetext{
${ }^{3}$ For the thought that fine things are difficult, cf. Plato, Republic iv 435c; vi 497d; Cratylus 384a-b; Hippias Major 304e. On the different ways Socrates tries to exhort his various students with the claim that "fine things are difficult," see Mintz 2010.
} 
understanding what philosophy's easiness has to do with its choiceworthiness for its own sake, and, therefore, of why Aristotle appeals to philosophy's easiness in a protreptic work. ${ }^{4}$

The Protrepticus' easiness arguments themselves raise multiple philosophical questions. For the purposes of this paper, however, it suffices to understand why Aristotle appeals to easiness in a protreptic work. I briefly situate the Protrepticus' easiness arguments in their dialectical context. On this basis, I elucidate what sort of easiness Aristotle attributes to philosophy, what difference philosophy's easiness makes to its choiceworthiness as an end, and how Aristotle can respond to the tripartite obvious normative worry just articulated.

\section{Understanding Isocrates' Demandingness Worry}

I begin with the commonly accepted proposal that, in the Protrepticus, Aristotle aims to respond to a set of challenges from Isocrates, a thinker who opposed Plato and Aristotle's theoretical conception of philosophy in favor of a model of philosophy focused on the art of rhetoric. ${ }^{5}$ One need not accept Hutchinson and Johnson's proposal that the Protrepticus was originally a dialogue, strictly speaking, to agree that the Protrepticus incorporates distinct Isocratean, Aristotelian, and Pythagorean voices. ${ }^{6}$ In DCMS 26, 79.5-15, which Hutchinson and Johnson now attribute to Aristotle's Protrepticus, an Isocratean voice addresses the views of rival philosophers. Some philosophers, the Isocratean voice says, pursue the sort of scientific understanding of nature sought by Anaxagoras and Parmenides. Other philosophers seek a theoretically grounded account of the just and the good.

\footnotetext{
${ }^{4}$ Thanks to Jerry Green for questions on these passages. On the philosopher's "love of

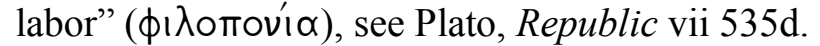

${ }^{5}$ See, e.g., Einarson 1936: 272-278; Düring 1961: 20-24, 33-35; Jaeger 1962: 55-60; Van der Meeren 2011: xxvi-xxx; Wareh 2012: 41-42; Collins 2015: 244-245, 255-257; Hutchinson and Johnson unpublished work B.

${ }^{6}$ Cf. Collins 2015: 245; Wareh 2012: 17.
} 
Nevertheless, these rival conceptions of philosophy, the Isocratean voice contends, prove useless and not worth the effort.

I note the similarity of DCMS $26,79.5-15$ to passages in Isocrates' corpus in particular, to passages in the Antidosis, a work with which Aristotle shows explicit familiarity in the Rhetoric. $^{7}$ In the Antidosis, Isocrates opposes rival - that is, theoretical philosophers, who focus on "astronomy and geometry and studies of that sort" (261). ${ }^{8}$ Such philosophers seek an understanding beyond the grasp of finite human beings: such philosophers "promise to make their disciples all but immortal" (Against the Sophists 4). Yet human beings are finite, and such investigations ill suit human nature. Hence, Isocrates implores, students should not "allow their minds to be dried up by these barren subtleties, nor stranded on the speculations of the ancient sophists" (Antidosis 268).

Given our human limitations, Isocrates thinks, theoretical investigations are simply impossible to complete successfully. On this basis, Isocrates rejects the very possibility of

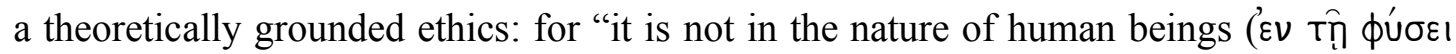
Tก̣ $\left.\tau \hat{\omega} \nu \alpha{ }^{\prime} \nu \rho \omega \dot{\pi} \omega \omega \nu\right)$ to attain an understanding by the possession of which we can know positively what we should do or what we should say" (Antidosis 271). ${ }^{9}$ Similarly, theoretical investigations into the fundamental nature of reality show no signs of attaining the understanding that they seek. Instead, such investigations break down into interminable,

\footnotetext{
${ }^{7}$ Cf. Antidosis 173 and Rhetoric II.23, 1399b9-11; cf. Antidosis 132-139; 141-149 and Rhetoric iii 17.1418b27. See Hutchinson and Johnson unpublished work B on the Rhetoric's quotation of the Antidosis. On references to Isocrates' works throughout the Rhetoric, see Veteikis 2011. Plato, meanwhile, was also familiar with Isocratean worries about Academic philosophy: see Phaedrus 278e-279b; Gorgias 463a (cf. Against the Sophists 17), 484c-485d (cf. Antidosis 267-268).

${ }^{8}$ Translations of Isocrates are from the Loeb editions, sometimes with slight emendation.

${ }^{9}$ Here, Isocrates conflates two views: (a) that no kind of knowledge can issue precise prescriptions for particular situations (see Antidosis 184) and (b) that no kind of knowledge can inform action (see Against the Sophists 2-4). Aristotle agrees with Isocrates on (a): see, e.g., $E N$ i 3.1094b13-27; vi 1.1139a6-17; vi 5.1140a33-b4. But Aristotle disagrees with Isocrates on (b): see, especially, Protrepticus 10 (and Walker 2018: 145-150). On Aristotle's agreements and disagreements with Isocrates, see Depew 2004: 169-173 and Wareh 2012: ch. 1.
} 
“eristic" disputes (Antidosis 84; Panathenaicus 26-29; Against the Sophists 1; Helen 1-6). Some theoretical philosophers, such as Empedocles, contend that there are four basic elements in nature; others, such as Gorgias, deny that there are any (Antidosis 268). Such theoretical inquiries, however, are "vain" (Antidosis 269), and evidently unsuccessful in their own aims. In a key sense, and in virtue of our human limitations, then, theoretical philosophy is an impossible enterprise. Such philosophizing sufficiently overstrains our capacities. Hence, Isocrates thinks, rival theoretical conceptions of philosophy are excessively demanding, and inevitably too toilsome and laborious to be fitting objects of diligent pursuit for their own sakes. Call this Isocrates' demandingness worry about rival theoretical conceptions of philosophy.

According to the Antidosis, true philosophy consists in those studies that enable a student to be wise. Wisdom, in turn, consists in the capacity to speak well, where such speaking constitutes the perfection of the student's capacities for thought, especially in practical affairs $(255 ; 285) .{ }^{10}$ Again, Isocrates criticizes the theoretical studies that his rivals emphasize for pursuing an impossible task. Yet Isocrates allows that such studies can benefit students, though in a limited, incidental way, and only with significant qualification (261). Laboring through ( $\left.\delta ı \alpha \pi \circ \eta \theta^{\prime} \varepsilon \nu T \varepsilon \varsigma\right)$ such studies and the exact reasoning that they display, like laboring through grammar and music, Isocrates grants, can sharpen our minds. Hence, they can prepare us to handle "easily" (jộov) the cognitive tasks that Isocrates views as more useful and more valuable (265). At best, however, these theoretical studies

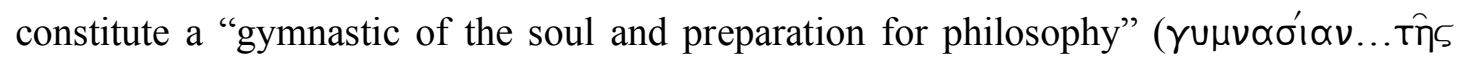

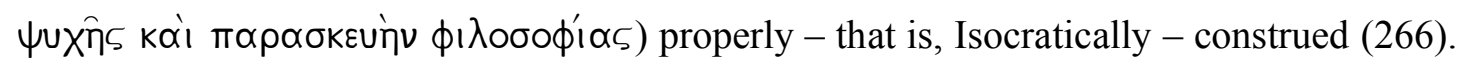
Like other gymnastics, theoretical studies are overall laborious in themselves, only

\footnotetext{
${ }^{10}$ On Isocrates' conception of philosophy, see Nightingale 1995: 26-28; Cooper 2004: 7177; Depew 2004; Wareh 2012; Collins 2015: 174-177.
} 
instrumentally valuable, and injurious when pursued too long and too far. For Isocrates, such studies are surely too toilsome to be choiceworthy for their own sakes.

To be clear, Isocrates admits that all types of knowledge are attained only "after great effort" (Antidosis 201), when good teachers habituate their students "to labor" for learning (

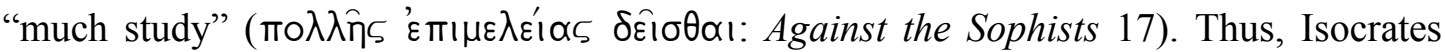
bemoans that it is hard to persuade the young to look down upon a life of ease and instead apply themselves to philosophy in his favored sense (Antidosis 305). Likewise, Isocrates emphasizes the need to exert effort to become virtuous. Whereas hesitancy (or sloth) is a fault, a certain labor is commendable (To Demonicus 7-9, 21), as is a certain "love of labor"

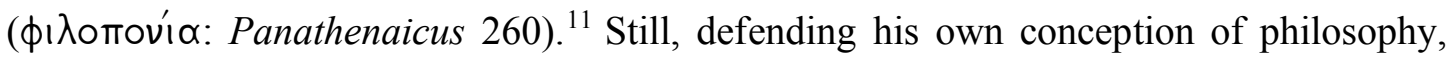
Isocrates insists that grasping the "forms" out of which to compose speeches "is not

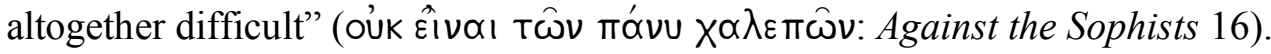

Isocrates' point raises an obvious question: since difficulty seems ineluctably relational (to an agent or class of agents), for whom does Isocrates believe that his rhetorical philosophy is "not altogether difficult"? Isocrates seems, in some passages, to offer a narrow answer to this question. He insists that people require the right nature if they are apt to excel at his art (Antidosis 186-187; cf. Against the Sophists 10,17), and that natural ability is of greatest importance (Antidosis 189). Further, he suggests that only some are

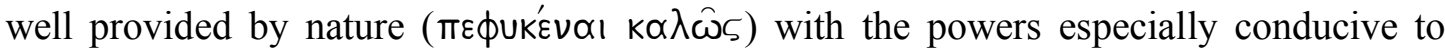
becoming a philosopher. These powers include the capacity to learn, a strong memory, a clear voice, and confidence (Antidosis 187-190). Hence, Isocrates, at points, seems to hold that rhetorical philosophy is "not altogether difficult" for that select group with the right nature for it. In other passages, however, Isocrates suggests a broader answer to this

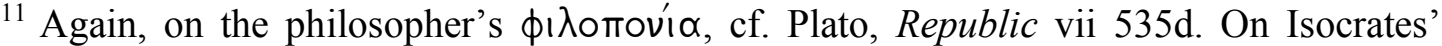
exhortations to hard work, see Wareh 2012: 32-33.
} 
question. Whereas it does not belong to "the nature of human beings" to attain theoretical philosophy's aims successfully (Antidosis 271), he says, rhetorical philosophy does not face this problem. For even if a rhetorical-philosophical education cannot make those without natural aptitude good debaters or speech-makers, this education can nevertheless

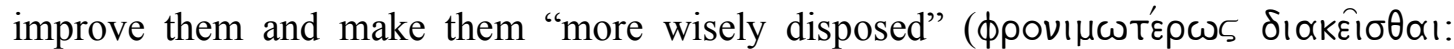
Against the Sophists 15). Indeed, Isocrates admits that, with experience and discipline, even

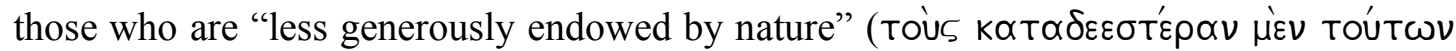

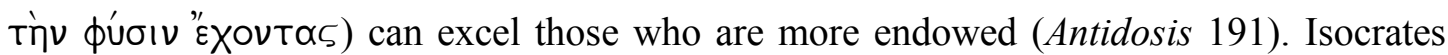
believes, then, that his own rhetorical philosophy is "not altogether difficult" (in particular) for those with the right nature for it. At the same time, Isocrates believes that such philosophy is "not altogether difficult" (more broadly) for human beings as such, provided that they take care to cultivate their abilities. ${ }^{12}$

In sum, unlike his rivals' theoretical philosophies, Isocrates suggests, his own rhetorical mode of philosophy is not excessively demanding. It is not completely difficult (i.e., impossible) for human beings as such. Nor is it overall difficult for human beings (i.e., capable of some qualified realization, but only at the cost of substantially greater toil). $\mathrm{He}$ thus denies that his model, in either way, amounts to sheer drudgery for those with, or without, special natural aptitude. At the same time, Isocrates does not try to pass off his model as completely easy, that is, as effortlessly simple for human beings as such. For philosophy, he admits, still requires some work and effort. Instead, Isocrates presents his own model as somewhat difficult, but overall easy. He grants that it imposes a certain labor. Yet he denies that this labor is significantly, or at all, greater than the one's ability to realize this model. For those with special natural aptitude, his own model comes easier than it does

\footnotetext{
${ }^{12}$ Bradford 2015: 27-28 suggests that difficulty is always relative to an agent or class of agents. On Isocrates on the individual's nature, see Wareh 2012: 27-34.
} 
to those without such aptitude. Yet for both kinds of people, rhetorical philosophy, though requiring some work, remains generally feasible.

II. Addressing the Normative Worry, Part (1): The Sufficiency of Easiness?

With these points in mind, I now return to Aristotle. On the one hand, he defends theoretical philosophy as choiceworthy for its own sake. On the other hand, Aristotle confronts both Isocrates' demandingness worry and Isocrates' positive claims for the general feasibility of his alternative rhetorical model of philosophy. Within this dialectical context, Aristotle has good reason to argue that, for human beings as such, theoretical philosophy need not, by nature, constitute sheer drudgery. Aristotle, in other words, has good reason to show that such philosophy is neither (a) completely difficult nor (b) overall difficult. Instead, Aristotle has reason to show that philosophy is, in both ways, practicable. Indeed apparently like Isocrates - Aristotle assumes that practicability (i.e., being duvatós) is one of many necessary conditions for an activity's being good or such-as-to-be-chosen (Rhetoric i 6.1363a20-21). And activities, he notes, are practicable in two ways ( $\delta ı \times \omega \hat{\zeta}$ ), viz., insofar as they belong to the class of (i) the possible and (ii) the easy to perform (Tó

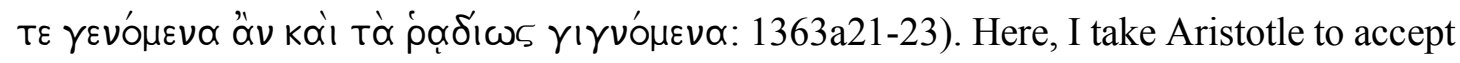
that such modes of practicability constitute a conjunctive necessary condition for an activity's choiceworthiness, at least for its own sake.

Accordingly, I introduce a distinction. When some activity is at least possible, it possesses weak practicability. In this case, the activity is not inconsistent with human nature; for human beings can perform it successfully. Yet that activity, even if possible, might still be overall difficult: it might still impose overall heavy costs of painful effort and time, the two markers of difficulty that Rhetoric i $6.1363 \mathrm{a} 23$ highlights. Therefore, when an activity is at least overall easy to perform, it possesses strong practicability. In this case, 
the activity need not require such heavy costs of painful effort and time. And so, instead, the activity positively accords with human nature.

Suppose, then, that Aristotle can show that theoretical philosophy is both possible and easy to perform - i.e., that such philosophy possesses both weak and strong practicability. In this case, Aristotle can fully address Isocrates' demandingness worry. For he can thereby show that theoretical philosophy is neither (a) completely difficult nor (b) somewhat easy, but overall difficult. ${ }^{13}$ Theoretical philosophy, contrary to Isocrates, can attain its ends of understanding. Further, it can serve as more than an onerous gymnastic of the soul possessing only qualified, instrumental choiceworthiness. Hence, Aristotle can argue, theoretical philosophy can be choiceworthy for its own sake.

In conceding Isocrates' assumption that excessive demandingness precludes something's choiceworthiness for its own sake, and that both weak and strong practicability are necessary conditions for such choiceworthiness, Aristotle accepts a plausible view. For he then accepts the view that pursuits choiceworthy as ends should neither conflict with, nor otherwise overstrain, human powers. After all, he believes that our good consists in our being fully and virtuously active as the kinds of beings we are. Choiceworthy activities, then, must be possible for us. In-principle impossible tasks are not worth pursuing: they are pointless. Meanwhile, even if activities choiceworthy as ends inevitably impose some burdens on us, such activities should at least not be overall difficult. ${ }^{14}$ Instead of overstraining human powers, they should be generally feasible for us as well. Any burdens

\footnotetext{
${ }^{13}$ When Topics iii $1.116 \mathrm{~b} 26$ suggests, without explanation, that what is practicable is more choiceworthy than what is not practicable, I take Aristotle to mean that what is practicable is trivially more choiceworthy than what is not practicable, since weak practicability (at least) is a necessary condition of any choiceworthiness.

${ }^{14}$ Aristotle sometimes suggests that our good consists in approximating divinity as far as possible: see, e.g., EN x 7. 1177b27-33. As I argue in Walker 2018: 93-98, however, Aristotle means that we should approximate divinity - exercise our powers - as far as possible within the constraints of our human nature. The good we seek, Aristotle holds, is the human good (cf. EN i 7.1097a15 and 1098a16; i 13.1102a12-17). Thus, Aristotle's exhortations to immortalize ourselves do not amount to exhortations either to accomplish the impossible or otherwise to overstrain our humanity.
} 
that such activities impose should be compensated for, viz., by other, easiness-conducive features of the activities in question. Otherwise, the activities are overall toilsome, and, if considered as potential ends, unprofitable and wastes of vital effort. (Activities that are merely instrumentally choiceworthy - e.g., having painful medical surgery - may well be overall difficult, but still worth pursuing for other ends.)

How, then, does Aristotle show that theoretical philosophy meets both the weak and the strong practicability conditions? Outside the Protrepticus, Aristotle rejects the thought that attaining philosophical understanding is impossible. By defending the inprinciple possibility of attaining philosophical understanding, then, Aristotle shows that theoretical philosophy meets the weak practicability condition. In Metaphysics A 2.982b28-32, for instance, Aristotle considers the worry that wisdom ( $\sigma \circ \phi^{\prime}(\alpha)$ is not properly human, that gods alone are privileged to be wise, and that human beings should therefore content themselves with the understanding that accords with their abilities. In his discussion, Aristotle attributes this worry to Simonides. ${ }^{15}$ In response, Aristotle denies that

${ }^{15}$ Kurke 2011: 122 notes Aristotle's transformation of the point of Simonides' poem. According to parts of Simonides' poem preserved in Plato's Protagoras (341e), the privilege proper to the gods is not sophia, but utter perfection. Aristotle, then, imports Simonides' view about the difficulties of becoming virtuous into Metaphysics A's opening discussion of first philosophy.

Consider, further, the context in which Simonides' poem comes up for discussion in the Protagoras. How can Simonides hold that it is hard for human beings to become good (339b), yet also cast doubt on Pittacus' claim that it is hard to be good (339c)? In the Protagoras, Prodicus participates in the discussion, distinguishing becoming and being (340b). On this basis, and alluding to Hesiod's Works and Days 287-319, Socrates suggests that while becoming good is hard, being good is easy (340d). The Protagoras' references to Prodicus and Hesiod invite comparison with similar references in Xenophon's Memorabilia II.1.21-33 (=DK 84B2). Here, Xenophon's Socrates alludes to Prodicus' Choice of Heracles, in which Heracles finds himself faced with choosing between two roads, the road of Virtue, who presents herself as difficult, but rewarding, and the road of Vice, who promises to be easy. For its part, Prodicus' Choice of Heracles, however, borrows and reinterprets Works and Days 287-319. Van der Meeren 2011: 109n10 notes some of these resonances.

While I focus on Isocrates' criticisms of natural philosophy as providing the immediate context for Aristotle's arguments in Protrepticus 6, the Isocrates-Aristotle dispute takes place against a larger background debate concerning the difficulties of virtue generally. On some of this background, see Wolfsdorf 2008; Beresford 2008 and 2009. I say more on 
wisdom exceeds human capacities, and he asserts that the gods are pleased when human beings share in wisdom. To be sure, Aristotle goes on to write the Metaphysics, which develops first philosophy and shows, at least by example, that wisdom remains within human powers. ${ }^{16}$ Yet Metaphysics A 2 does not provide any argument explicitly defending the claims about wisdom that Aristotle asserts there.

In the Protrepticus, however, Aristotle directly defends philosophy's weak practicability. Aristotle's defense begins with a general argument for the very possibility of philosophy, i.e., for the view that philosophizing successfully lies within human powers $(6,38.3-39.8 / \mathrm{B} 31-36)$. Briefly, Aristotle argues that fundamental explanatory principles and causes are more understandable than that which they explain. Human beings by nature can understand all sorts of things. Therefore, a fortiori, they must be able to grasp fundamental explanatory principles and causes.

This argument, if successful, shows that theoretical philosophizing successfully is at least possible. If so, such philosophy proves possible in a more complete sense than Isocrates allows. For we can successfully attain the understanding that our philosophizing seeks. Such philosophy, then, need not be excessively demanding in one respect: it need not be completely difficult, i.e., sheer toilsome wheel-spinning. Yet such philosophy, for all that, might remain excessively demanding in another respect: it might still remain overall difficult. And Aristotle is clear that wisdom, as a universal science whose objects are least open to our senses, does impose certain difficulties (Metaphysics A 2.982a23-25; cf. EN vi 7.1141b6-8; Protrepticus 6, 38.14-22/B34; 7, 44.17-26/B76-77). Showing that theoretical philosophy possesses weak practicability and is possible does not yet show that such philosophy possesses strong practicability and is generally feasible.

Aristotle's stance concerning the difficulty of virtue in §IV below. (I thank an anonymous referee for calling attention to these matters.)

${ }^{16}$ I thank Ronald Polansky for this point. 
Establishing theoretical philosophy's general feasibility, and thereby responding completely to Isocrates' demandingness objection, then, is the task of Protrepticus 6's easiness arguments. Such arguments can admit that theoretical philosophy, requiring effort, is not effortlessly simple or completely easy. The difficulties that such philosophy imposes are real. Yet Aristotle's arguments, if successful, show that such philosophizing need not, by itself, be even overall difficult. For if these arguments are successful, any difficulties with which philosophizing presents us can be outweighed and counteracted by philosophy's compensating, easiness-conducive features. Such philosophy has features, as Aristotle argues, that have enabled it to outstrip the other arts in a short time, to be pleasant in leisure, and to attain its ends without requiring burdensome external resources. Even if theoretical philosophy is somewhat difficult, it remains overall easy - that is, generally feasible. ${ }^{17}$

We can now respond to part (1) of the obvious normative worry, i.e., the thought that easiness does not suffice for an activity's choiceworthiness for itself. Aristotle can agree: many vicious deeds may well be easy, but best avoided. By defending theoretical philosophy's easiness, however, Aristotle need not be arguing that easiness is, all by itself, one of philosophy's (unqualified) good-making features, or that one should philosophize for the sake of its easiness. Easiness is only a necessary condition for something's choiceworthiness for its own sake. According to Protrepticus 7, philosophy is choiceworthy for its own sake because of its other features, including (a) its status as the function of our highest virtue and (b) its being the sort of activity through which we attain

\footnotetext{
${ }^{17}$ Demonstrating philosophy's easiness thus accords with the independently sensible advice of the later, pseudo-Aristotelian Rhetoric to Alexander, which recommends that protreptic arguments emphasize the easiness of the relevant end or pursuit $(1,1421 \mathrm{~b} 24$; cf. 3, 1426a1). The Rhetoric to Alexander is often attributed to Anaximenes of Lampsacus. In virtue of multiple structural similarities between Aristotle's Rhetoric and the Rhetoric to Alexander, Mirhady 2007: 4-6 speculates that both Aristotle and Anaximenes may have borrowed from an earlier rhetoric handbook, perhaps by Theodorus of Byzantium.
} 
the fullest degree of vitality. ${ }^{18}$ Further, in Protrepticus 10, Aristotle attributes utility to philosophy for deriving boundary markers of the human goods. (Thus, in his introductory remarks to Protrepticus 6, Iamblichus suggests that any costs that philosophy imposes with respect to difficulty will also turn out to be outweighed by the greatness of philosophy's usefulness [37.22-26/B31].) In sum, Aristotle's easiness arguments promise to show contrary to Isocrates - that philosophy is not excessively demanding, and that human beings as such are naturally well suited for philosophy.

III. Addressing the Normative Worry, Part (2): The Necessity of Easiness?

This response, however, confronts Aristotle with part (2) of the obvious normative worrythe thought that easiness does not, after all, seem to be necessary for something's choiceworthiness as an end. Ethical virtue, it seems, is both difficult and choiceworthy for its own sake. At first blush, Aristotle might seem to portray ethical virtue in the way that Isocrates portrays philosophy, i.e., as overall difficult. It is hard, Aristotle says, to hit the intermediate with exceptional precision ( $E N$ ii 9.1109a34). For human beings find themselves, by nature, attracted to various pleasures (EN ii 8.1109a14-16). So, ethical virtue, even if possible, might still seem to overstrain human nature and lack strong practicability. But if so, then it is unclear how something's choiceworthiness for its own sake depends on its easiness. And if ethical virtue can be choiceworthy as an end even if overall difficult, then, presumably, the same should hold for philosophy. Therefore, it is unclear why Aristotle should defend philosophy's easiness.

Yet I deny that Aristotle ultimately identifies ethical virtue as overall difficult in this sense. True, we face impediments to acquiring and exercising ethical virtue insofar as we must counteract certain tendencies that we possess qua animal. Chief among these impediments is our predisposition to pleasure. Moreover, given his views on natural

\footnotetext{
${ }^{18}$ On (a), see Protrepticus 7, 41.24-43.5/B61-67. On (b), see 7, 43.27-44.26/B71, 74-77.
} 
character, Aristotle is committed to holding that becoming virtuous will be harder for some people than for others. ${ }^{19}$ Nevertheless, ethical virtue should not, in general, be overall difficult, either for those with good natures or for human beings as such. For Aristotle explicitly denies that we possess ethical virtue "contrary to nature" ( 1.1103a24), at least in any strong sense. Instead, ethical virtue completes and manifests our human nature. For this reason, Aristotle affirms that happiness is available to all ( $\pi \hat{\alpha} \sigma ı)$ through a certain learning and care $(E N$ i $9.1099 b 18-20) .{ }^{20}$ Ethical virtue, then, is not effortlessly simple. But it is only somewhat difficult, not overall difficult. And Aristotle identifies easiness-conducive features of ethical virtue that sufficiently compensate for any of these incidental difficulties. (Whether we actually all do commit ourselves to the learning and care happiness requires is, for Aristotle, another matter.)

First, Aristotle highlights ways in which human beings can overcome any natural impediments to becoming ethically virtuous. In particular, good laws provide the right kind of nurture, especially when we are young, for counteracting our tendencies toward pleasure. Just as tilling the soil positively conduces to the seed's growth, stabilizing a human soul early on through the influence of good laws positively conduces to the development of ethical virtue (EN x 9.1179b23-26). Aristotle makes a similar point in Protrepticus 9. Nature, Aristotle says, easily completes some tasks by herself, but other tasks only with difficulty. Some seeds germinate when unattended; but others require farming. So, too, some animals actualize their full nature unattended; but other animals - in particular, human beings - require the right nurture (50.2-12/B13).

If such measures fail to benefit one early on, Aristotle recognizes, it is "difficult" $\left(\chi \propto \lambda \varepsilon \pi^{\prime}{ }^{\prime}\right)$ for one to turn toward virtue later $(E N \times 9.1179 \mathrm{~b} 31-1180 \mathrm{a} 1)$. For then, our animal predispositions toward pleasure remain obstacles to progress. When good laws and

\footnotetext{
${ }^{19}$ See Leunissen 2017: ch. 2, especially 48, 53.

${ }^{20}$ Those whom Aristotle identifies as natural slaves are presumably exceptions.
} 
caregivers intervene in the early nurture and ethical development of the young, however, they make virtuous dispositions customary. Under such conditions, acquiring virtuous

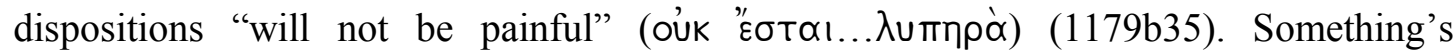
difficulty, however, consists, in part, in its painfulness (Rhet. i 6.1363a23-24). Therefore, given good laws and caretakers, developing virtuous dispositions should not be overall difficult.

Second, Aristotle denies that exercising ethical virtue must be overall difficult. Granted, Aristotle admits the difficulty of finding the intermediate with extreme precision: this is not a task that everyone can perform (EN ii 9.1109a25-29). Yet immediately after making this point, Aristotle emphasizes that human beings have at hand a readily available "second sailing." As practical agents, we can head toward the extreme opposed to that toward which we tend usually to drift (EN ii 9.1109b1-7), and we can resist pleasure (1109b7-12). By doing so, Aristotle affirms, we will err less and will most of all succeed in finding the intermediate (1109b12-13). We will thereby find the intermediate in the "easiest" ( $\rho \hat{\alpha} \sigma \tau \alpha)$ way (1109b26). True, the "easiest" way to find the intermediate need not always be easy tout court, any more than the richest beggar is rich. ${ }^{21}$ But in the context, Aristotle identifies feasible ways in which agents can non-strenuously overcome obstacles to exercising virtue.

Therefore, Aristotle thinks, acquiring and exercising ethical virtue is neither effortlessly simple nor completely easy. Instead, it is somewhat, but not overall, difficult. But notice, then, what type of difficulty Aristotle attributes to ethical virtue. An activity is generally feasible, as opposed to effortlessly simple, when it requires work, but when this work does not make the activity overall difficult. Consequently, the qualified difficulty that Aristotle attributes to ethical virtue turns out to be the same condition as ethical virtue's general feasibility, only under a different description. Acquiring and exercising ethical

\footnotetext{
${ }^{21}$ I thank an anonymous referee for this point.
} 
virtue is (somewhat) difficult (when compared to effortlessly simple tasks). And acquiring and exercising ethical virtue, as noted, may well be more difficult for some than for others. ${ }^{22}$ Yet these tasks remain (overall) easy (when compared to impossible or overall difficult tasks).

In short, Aristotle does identify ethical virtue as difficult, but still choiceworthy for its own sake. Ethical virtue's particular sort of difficulty turns out, however, to be fully compatible (because coextensive) with ethical virtue's general feasibility. Accordingly, Aristotle's admission that ethical virtue is difficult, but still choiceworthy for its own sake, coheres with the Protrepticus's appeal to easiness to defend philosophy's choiceworthiness. For Aristotle thinks that both ethical virtue and philosophy are choiceworthy for their own sakes when they are generally feasible - a condition that is consistent with their also being "difficult" in the qualified sense of not being effortlessly simple.

Whether Aristotle describes a given activity as "easy" or "difficult" depends on his sense of his audience. In Protrepticus 6, Aristotle faces an audience worried that philosophy is too difficult for mere mortals. In these circumstances, Aristotle's exhortations encouragingly highlight philosophy's easiness. In Nicomachean Ethics ii 9.1109a28-30, by contrast, Aristotle aims to articulate how we can best attain the intermediate in action. In this context, he emphasizes that this task is not effortlessly simple, for it requires some work. Moreover, it is work worth undertaking, given that virtue is fine and praiseworthy. In this way, Aristotle prepares his audience to take the steps necessary to attain virtue's rewards. ${ }^{23}$ Yet having made this point, Aristotle promptly clarifies that virtue's difficulty

\footnotetext{
${ }^{22}$ Connell 2018: 944 suggests that even if some people will, on Aristotle's view, find becoming virtuous "more difficult," becoming virtuous is a possibility "for a broad variety of humans."

${ }^{23}$ Cf. Alexander of Aphrodisias, Commentary on Aristotle's Metaphysics 140.8-9 on Aristotle's remarks on philosophy in Metaphysics $\propto$ 1.993a20: "Thus his words might be understood as an exhortation to us: on the one hand, not to take this study lightly, in the
} 
need not make the exercise of virtue overall burdensome or laborious. So, even here, Aristotle highlights ethical virtue's general feasibility. Hence, Aristotle's remarks on ethical virtue pose no problems for Aristotle's appealing to easiness in a philosophical protreptic. $^{24}$

IV. Addressing the Normative Worry, Part (3): The Superiority of the Difficult?

We still face part (3) of the obvious normative worry. How can Aristotle appeal to philosophy's easiness in a protreptic given his claims in (a) Rhetoric i 7.1364a29 and (b) Topics iii $2.117 \mathrm{~b} 28-30$ ? In these passages, it seems, Aristotle defends the superior value of what is difficult over what is easy. But his doing so apparently conflicts with the Protrepticus' assumption that philosophy's easiness somehow conduces to its choiceworthiness.

In response, (a) Rhetoric i $7.1364 \mathrm{a} 29$ does identify what is more difficult as, in some sense, more valuable than what is easy. Again, (a) holds that what is more difficult is, in some way, "greater" than what is easy. Yet (a) does not necessarily identify what is more difficult as more choiceworthy than what is easy. For Aristotle immediately qualifies 1364a29's claim about the greater value of what is difficult. He affirms that, in another

belief that it is altogether easy, but on the other hand not to abandon it as if it were altogether difficult" (trans. Dooley).

${ }^{24}$ In Topics viii 14.163b9-18, Aristotle indicates that one requires a certain natural ability for discerning the true and false, a power that contributes to our knowledge and philosophical wisdom (163b9-18). Yet Aristotle does not think that this point implies philosophy's overall difficulty. (1) He affirms that, in general, human beings are "sufficiently suited by nature for the true, and for the most part happen upon the truth" (Rhetoric i 1.1355a15-17). (2) He suggests ways that pursuing philosophical truth as a collective enterprise can compensate for any limitations that we incur on account of our individual natural abilities (Metaphysics $\propto$ 1.993a30-b5). To say more about how the collective character of philosophical inquiry on Aristotle's view enables human beings successfully to attain philosophical truth, however, would require one actually to address Protrepticus 6's actual arguments for the easiness of philosophy, in particular, the progress argument. See Walker forthcoming. 
way, what is easy has greater value than what is difficult. For what is easy "holds as we

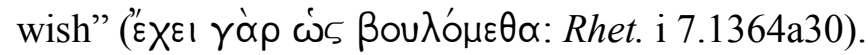

What is going on here? To square (a) with Aristotle's apparent reversal in the very next line (1364a30), I contend that (a) attributes "greater" value to what is difficult, but only in a distinct and qualified way. More specifically, we should read (a) as holding only that what is more difficult to obtain is more valuable qua having a higher price than what is easy. So construed, (a) holds that what is more difficult to obtain (perhaps because it is rarer, and because this rarity imposes an impediment to acquisition) costs more than what is easy. Thus, (a) makes a plausible point: what is difficult to obtain is more expensive (with respect to time, painful effort, and external resources) than what is easy. ${ }^{25}$ But (a) need not imply that what is difficult is more choiceworthy than what is easy - especially for the agent who faces the labor and toil of acquiring what is difficult. From the perspective of such an agent, what is easy "holds as we wish": for what is easy is not overall laborious or toilsome; and, rationally, we wish to avoid labor and toil as such. ${ }^{26}$

What about (b) Topics iii 2.1176b28-30? Initially, this passage is hard to decipher, for the text of (b) is missing both a comparison term and a verb. Hence, in the immediate context, (b) leaves unclear the precise sense in which the more difficult is more valuable than the easy. Still, I argue that (b) is open to a reading similar to (a) - a reading according to which Aristotle is simply highlighting the higher price of what is difficult. On this reading, just as what is more conspicuous has a higher price than what is less conspicuous, so too what is more difficult to obtain has a higher price than what is easy to obtain. When

\footnotetext{
${ }^{25}$ As Protrepticus 6, 40.15-41.2/B55-56 goes on to argue, philosophy is easy in not requiring an expenditure of time, painful effort, or resources. On $X$ 's difficulty as consisting in $X$ 's requiring a long time or painful effort, see Rhetoric i 6.1363a23-24.

${ }^{26}$ I adopt this thought from Cope (1877) 2009: 130-131, who suggests that Aristotle identifies what is difficult as more valuable than what is easy in respect of price. See also Aristotle's remarks on gold in the preceding lines (1364a23-28). Gold, which is rare, has a higher price than iron, which is less rare. Yet what is less rare - water - is often more choiceworthy from the perspective of our using it.
} 


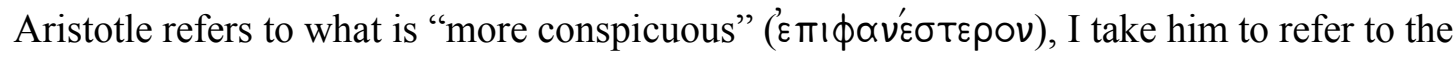
kinds of limited-supply items that one might wish to show off. Given their rarity, such items are expensive, and obtaining them imposes special costs on us. Similarly, Aristotle suggests, what is difficult to obtain imposes special costs on us as well.

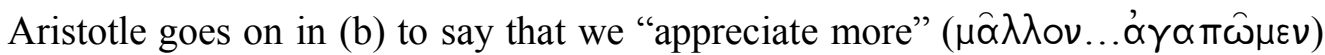
having what is difficult to acquire. By making this claim, however, Aristotle may simply be reporting our natural response to obtaining what we acquire through labor. When people bear high costs and expenses in obtaining "the things coming about through labor" (T⿺辶

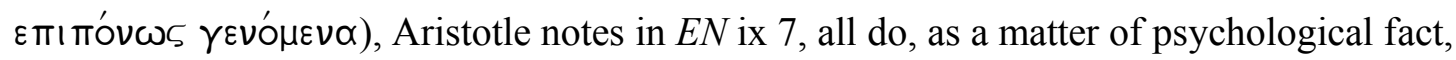
have a special affection ( $\left.\sigma \tau^{\prime} \varepsilon \rho \gamma o v \sigma ı v\right)$ for such items. Those who earn money appreciate it more than that who inherit it; mothers who suffer labor pains appreciate their children more than fathers do (1168a21-27; cf. Plato, Republic i 330c). In this way, at least, we do "appreciate more" what we have expended much effort to obtain. Yet again, these points about the high price of what is difficult do not entail that what is more difficult is more choiceworthy than what is easy. For as already noted, Rhetoric i 7.1364a30 points out that, ceteris paribus, we do wish to forego the labor and toil that the difficult imposes on us. Therefore, (a) and (b) do not pose problems for Aristotle's argumentative strategy in Protrepticus 6.

In conclusion, then, we have made progress in clarifying what precisely the Protrepticus' easiness arguments aim to accomplish. And we have seen how Aristotle can respond to the obvious normative worry in its three facets. The apparent tensions between Aristotle's appeal to philosophy's easiness in the Protrepticus and his remarks on choiceworthiness and difficulty elsewhere can be relieved. Accordingly, we can begin to take up the generally feasible work - but not necessarily the unduly toilsome labor required to examine Aristotle's easiness arguments fully, and to explore the question with 
which these arguments confront us: is philosophy, after all, easy for human beings as such $?^{27}$

Humanities Division (Philosophy)

Yale-NUS College

Singapore 138533

\footnotetext{
${ }^{27}$ I have presented material from this paper at the Rutgers University Classics Department; the Society for Ancient Greek Philosophy; the Ancient Philosophy Workshop at the University of Texas at Austin; the Nanyang Technological University Philosophy Department; the National University of Singapore Philosophy Department; the Pacific APA; the Workshop in Ancient Philosophy at the University of Oxford; "Philosophy in its Ancient Beginnings: On the Conceptualization, Criticism, and Justification of Philosophy in Antiquity" (a conference organized by Ronja Hildebrandt and Christopher Roser at Humboldt-Universität zu Berlin); and the University of Hong Kong Philosophy Department. I thank the audiences at these venues for their comments and suggestions. Among many in this group, I am particularly grateful to Matthew Evans, Gail Fine, Jessica Gelber, Monte Ransome Johnson, Andres Luco, Sara Protasi, and Franco Trivigno for their questions and comments. For helpful written feedback, I owe special thanks to Jerry Green (who challenged me to think harder about some of the normative worries this paper addresses), Verity Harte, D. S. Hutchinson, Brad Inwood, Neil Mehta, anonymous referees, and Ronald Polansky.
} 


\section{References}

Barnes, J., ed. 1984. The Complete Works of Aristotle: The Revised Oxford Translation. Princeton: Princeton University Press.

Beresford, A. 2008. "Nobody's Perfect: A New Text and Interpretation of Simonides $P M G$ 542." Classical Philology 103: 237-256.

----- 2009. "Erasing Simonides.” Apeiron 42: 185-220.

Bradford, G. 2017. Achievement. Oxford: Oxford University Press.

Bywater, I. 1869. “On a Lost Dialogue of Aristotle.” Journal of Philology 2: 55-69.

Cambiano, G. 2012. "The Desire to Know: Metaphysics A.1." In Aristotle's Metaphysics Alpha: Symposium Aristotelicum, ed. C. Steel and O. Primavesi, 1-41. Oxford: Oxford University Press.

Collins, J. H. 2015. Exhortations to Philosophy: The Protreptics of Plato, Isocrates, and Aristotle. Oxford: Oxford University Press.

Connell, S. M. 2018. "Review of Mariska Leunissen, From Natural Character to Moral Virtue in Aristotle." Mind 127: 938-946.

Cooper, J. M., ed. 1997. Plato: Complete Works. Indianapolis: Hackett.

---- 2004. "Plato, Isocrates, and Cicero on the Independence of Oratory from Philosophy." In Knowledge, Nature, and the Good: Essays in Ancient Philosophy, 65-80. Princeton University Press.

Cope, E. M. ed. and comm. [1877] 2009. The Rhetoric of Aristotle, Vol. I. Rev. J. E. Sandys. Cambridge: Cambridge University Press.

Depew, D. 2004. "The Inscription of Isocrates into Aristotle's Practical Philosophy." In Isocrates and Civic Education, ed. T. Poulakos and D. Depew, 157-185. Austin: University of Texas Press.

Dooley, W. E. and A. Madigan, trans. 1992. Alexander of Aphrodisias: On Aristotle's Metaphysics 2 \& 3. London: Bloomsbury Academic.

Düring, I. ed. and comm. 1961. Aristotle's Protrepticus: An Attempt at Reconstruction. Goteborg: Studia Graeca et Latina Gothoburgensia.

Einarson, B. 1936. "Aristotle's Protrepticus and the Structure of the Epinomis." Transactions and Proceedings of the American Philological Association 67: 261-285.

Festa, N., ed. 1891. Iamblichi De Communi Mathematica Scientia. Leipzig: Bibliotheca Teubneriana.

Hutchinson, D. S. and M. R. Johnson, 2005. "Authenticating Aristotle's Protrepticus." Oxford Studies in Ancient Philosophy 29: 193-294. 
---- Hutchinson, D.S. and M. R. Johnson. 2018. "Protreptic and Apotreptic: Aristotle's Dialogue Protrepticus." In When Wisdom Calls: Philosophical Protreptic in Antiquity, ed. O. Alieva, A. Kotzé, and S. Van Der Meeren, 111-154. Turnhout: Brepols.

----- Unpublished. "The Antidosis of Isocrates and Aristotle's Protrepticus." www.protrepticus.info.

Jaeger, W. 1962. Aristotle: Fundamentals of the History of His Development, $2^{\text {nd }}$ ed. Trans. R. Robinson. Oxford: Oxford University Press.

Kurke, L. 2011. Aesopic Conversations: Popular Tradition, Cultural Dialogue, and the Invention of Greek Prose. Princeton: Princeton University Press.

Leunissen, M. 2017. From Natural Character to Moral Virtue in Aristotle. Oxford: Oxford University Press.

Marchant, E.C., ed. and trans. 1938. Xenophon: Memorabilia, Oeconomicus, Symposium, Apology. Cambridge, Mass.: Harvard University Press.

Mintz, A. I. 2010. "Chalepa Ta Kala," "Fine Things are Difficult": Socrates' Insights into the Psychology of Teaching and Learning. Studies in Philosophy and Education 29: 287299.

Mirhady, D. C., ed. 2007. Influences on Peripatetic Rhetoric: Essays in Honor of William $W$. Fortenbaugh. Leiden and Boston: Brill.

Most, G.W., ed. and trans. 2006. Hesiod I: Theogony, Works and Days, Testimonia. Cambridge, Mass.: Harvard University Press.

Nightingale, A. W. 1995. Genres in Dialogue: Plato and the Construct of Philosophy. Cambridge: Cambridge University Press.

Norlin, G., ed. and trans. 1928-1929. Isocrates I-II. Cambridge, Mass.: Harvard University Press.

Pistelli, H.G. 1888. Iamblichi Protrepticus. Teubner: Bibliotheca Scriptorum Graecorum et Romanorum Teubneriana.

Van der Meeren, S., ed., trans. and comm. 2011. Exhortation à la philosophie: Le dossier grec Aristote. Paris: Les Belles Lettres.

Van Hook, L., ed. and trans. 1945. Isocrates III. Cambridge, Mass.: Harvard University Press.

Veteikis, T. 2008. "References to Isocrates in Aristotle's Art of Rhetoric." Literatura 53: 7-40.

Walker, M. 2018. Aristotle on the Uses of Contemplation. Cambridge: Cambridge University Press. 
Walker, M.D. forthcoming. "Aristotle, Isocrates, and Philosophical Progress: Protrepticus 6, 40.15-20/B55." Jens Kristian Larsen and Philipp Steinkrüger edd. Logical Analysis and History of Philosophy issue on "Ancient Modes of Philosophical Inquiry."

Wareh, T. 2012. The Theory and Practice of Life: Isocrates and the Philosophers. Cambridge, Mass.: Center for Hellenic Studies.

Wolfsdorf, D. 2008. "Hesiod, Prodicus, and the Socratics on Work and Pleasure." Oxford Studies in Ancient Philosophy 35: 1-18. 